\title{
Assessment of an ultra-sensitive IFN $\gamma$ immunoassay prototype for latent tuberculosis diagnosis
}

\author{
Elyes Ben Salah ${ }^{1}$, Karim Dorgham ${ }^{1}$, Mylène Lesénéchal ${ }^{2}$, Camille Pease $^{2}$, Laure Allard ${ }^{2}$, Céline \\ Dragonetti $^{2}$, Guy Gorochov ${ }^{1}$, Amélie Guihot ${ }^{1}$, Delphine Sterlin ${ }^{1}$ \\ ${ }^{1}$ Sorbonne université, Inserm, Centre d'immunologie et des maladies infectieuses (CIMI-Paris), AP-HP, groupement hospitalier de la Pitié-Salpêtrière, \\ département d'immunologie, 75013 Paris, France \\ ${ }^{2}$ bioMérieux, R\&D Immunoassays, chemin de l’Orme, 69280 Marcy-l’Étoile, France
}

Correspondence: Sorbonne université, Inserm, U1135, CIMI-Paris hôpital de la Pitié-Salpêtrière, bâtiment Cervi, 83, boulevard de l'Hopital, 75013 Paris, France.

$<$ karim.dorgham@inserm.fr>

Accepted for publication October 11, 2018

To cite this article: Ben Salah E, Dorgham K, Lesénéchal M, Pease C, Allard L, Dragonetti C, Gorochov G, Guihot A, Sterlin D. Assessment of an ultra-sensitive IFN $\gamma$ immunoassay prototype for latent tuberculosis diagnosis. Eur. Cytokine Netw. 2018; 29(4): 136-45 doi:10.1684/ecn.2018.0417

\begin{abstract}
Worldwide there are about 1.7 billion individuals with latent tuberculosis infection (LTBI) and only $5 \%$ to $15 \%$ will develop active tuberculosis (TB). It is recommended to treat only those most at risk of developing active TB to avoid problems of drug resistance. LTBI diagnosis involves reviewing the individual's medical history, physical examination, and biological tests. Interferon gamma release assays (IGRA) can yield "undeterminate" or "uncertain" results, which makes clinical management decisions difficult. We assessed an ultra-sensitive immunoassay prototype based on single molecule array (SiMoA) technology to evaluate its overall performance, and in particular, its performance for indeterminate and uncertain positive or negative samples, as classified by the results from the current ELISA technique used for IFN $\gamma$ quantification. We analyzed samples from hospitalized or consulting patients and healthcare workers from three hospitals in Paris, previously classified as negative $(n=30)$, positive $(n=35)$, uncertain negative $(n=25)$, uncertain positive $(n=31)$, or indeterminate $(n=30)$. We observed that with the SiMoA assay $83.3 \%$ of the indeterminate samples became interpretable and could be classified as negative, whereas $74 \%$ of uncertain positive samples were classified as positive. Most uncertain negative samples (72\%) were reclassified as uncertain positive $(68 \%)$ or positive $(4 \%)$. The results suggest that the ultra-sensitive SiMoA IFN $\gamma$ assay could represent a useful tool for the identification of true positive and negative samples among those giving indeterminate or uncertain results with the TB IGRA assay currently used.
\end{abstract}

Keywords: latent tuberculosis infection, interferon gamma release assay, digital ELISA

\section{INTRODUCTION}

Tuberculosis (TB) is a bacterial infection caused by Mycobacterium tuberculosis complex that affects the lungs in about $70-80 \%$ of cases $[1,2]$. When people with pulmonary TB cough, sneeze, or spit the bacteria is expelled into the air and other people can become infected by inhalation of only a few of the bacteria [1]. TB infection can be either active (disease state) or latent. TB is a major public health threat that has important medical and economic consequences. In 2017, about 10 million people were reported to have active TB and it was among the top ten causes of death worldwide, with 1.6 million deaths [1]. TB is responsible for about $40 \%$ of deaths in coinfected HIV patients [1].

The World Health Organization (WHO) defines latent tuberculosis infection (LTBI) as the persistence of an immune response to $M$. tuberculosis antigens, coupled with the absence of clinical signs suggestive of tuberculosis [3]. In 2014, it was estimated that there were about 1.7 billion individuals with LTBI, i.e., $23 \%$ of the global population
[4]. About 5\% to $15 \%$ of those with LTBI will develop active TB during their lifetime [5].

To prevent active TB from developing, individuals with LTBI can receive treatment, which is less intensive than treatment for active TB [6]. However, it is not recommended to treat everyone with LTBI to avoid problems of drug resistance, particularly multi-drug-resistant strains. The priority, therefore, is to identify those who are most at risk of developing active TB, i.e., those with an incompetent immune system, either due to disease, e.g. HIV or immunosuppressive therapy, such as anti-tumor necrosis factor alpha (anti-TNF- $\alpha$ ) therapies for the management of certain pathologies (e.g. Crohn's disease and rheumatoid arthritis). The growing number of people with LTBI that could potentially evolve to active TB underlines the need for reliable means to diagnose LTBI [7].

At present, LTBI is diagnosed using the patient's medical history, physical examination, and biological tests. These tests assess the capacity of the patient's immune system to recognize mycobacterial antigens, thereby providing indirect proof of infection $[8,9]$. The first test, developed in the 
early 20th century by Robert Koch, involved an intradermal injection of mycobacterial antigen extracts (tuberculin skin test, TST) that triggers an in vivo delayed hypersensitivity reaction, indicating the presence of a more or less specific immune response [10]. Recently, two more specific assays, i.e., interferon gamma release assays (IGRA), based on an in vitro immune response and subsequent secretion of interferon gamma (IFN $\gamma$ ) in whole blood samples have been developed, the QuantiFERON ${ }^{\circledR}$-TB Gold in-tube and T-SPOT.TB ${ }^{\circledR}$ [11-13]. These assays have significantly improved the diagnosis of LTBI because, unlike the TST, they do not cross-react with BCG (CalmetteGuérin bacillus). The most widely used TB IGRA test is the QuantiFERON ${ }^{\circledR}$-TB test (Qiagen, Hilden, Germany). The QuantiFERON ${ }^{\circledR}$-TB Gold in-Tube assay (QFT-GIT) is being replaced by the new-generation QuantiFERON ${ }^{\circledR}$ TB Gold Plus (QFT-Plus). These assays involve an in vitro stimulation of lymphocytes specific for the bacterial tuberculosis complex by a cocktail of peptides from two M. tuberculosis specific proteins (ESAT-6 and CFP10). This is followed by the quantification of IFN $\gamma$ produced in response to this stimulation (expressed as international units/mL [IU/mL]) using the same microplate QFT IFNy ELISA kit. Both QFT-GIT and QFT-Plus rely on a differential interpretation of different in vitro stimulations, based on the quantity of detected IFN $\gamma$. The negative control (NIL) provides information on the background level of IFN $\gamma$ in the sample at the time of testing and a positive control (MIT) validates the IFN $\gamma$ secretion capacity of $\mathrm{T}$ lymphocytes in the whole blood sample. In the QFT-GIT assay there is a single $M$. tuberculosis-specific stimulation (TB), compared with two (TB1 and TB2) in the QFTPlus assay. The test result is considered positive if the difference between the M. tuberculosis-specific stimulations (TB1 or TB2) and the negative control exceeds a predefined threshold. However, the QFT results are considered "indeterminate" when the positive control values are low or when there is a high background response to the negative control. Indeterminate results are often associated with immunodeficiency due to lymphopenia, HIV, or immunosuppressive treatments [14-19]. This immunodeficiency reduces the $\mathrm{T}$ lymphocyte population and, consequently, the amount of IFN $\gamma$ secreted is decreased. However, other factors can reduce the number of viable T-cells, e.g., delayed reception of samples in the laboratory and result in lower levels of secreted IFN $\gamma$ for the positive control [20-22]. High results for negative controls, either due to excessive levels of circulating IFN $\gamma$ or heterophilic antibodies, can also result in indeterminate results. The incidence of indeterminate results is usually low in healthy individuals $(<2 \%)$ but can increase significantly in immunosuppressed populations due to the lower secretion of IFNy and the level of the IGRA detection threshold [23, 24].

"Uncertain" results are linked to an additional uncertainty zone around the QFT manufacturer's predefined threshold. An "uncertainty zone" has been proposed to deal with variations occurring in the interpretation of results from serial QFT assays. In one study, assessing serial testing of samples from healthcare workers in a low-incidence setting using the QFT-GIT assay, the use of an uncertainty zone from 0.2 to $0.7 \mathrm{IU} / \mathrm{mL}$, instead of a strict threshold of $0.35 \mathrm{IU} / \mathrm{mL}$, resulted in a lower percentage of conversions and reversions (2.6\% versus $6.1 \%$ and $15.4 \%$ versus
$32.6 \%$, respectively) [25]. Several sources of variability that can have an impact on serial QFT testing were identified in a systematic review, with the QFT IFN $\gamma$ ELISA kit variability itself being the most important [26]. More recently, results from a study investigating the preanalytical, analytical, and inter-assay variability of the QFT-GIT assay demonstrated that the variability could be improved by implementing optimized procedures, some of which were linked to the combined effects of blood volume and incubation times in the QFT stimulation tubes and some linked to the QFT IFN $\gamma$ ELISA kit itself [27].

Overall, these observations suggest that a more sensitive, automated assay could provide a better clinical interpretation of the results for these specific patient populations. Recently, a highly-sensitive SiMoA prototype for IFNy quantification, based on single molecule array $\left(\mathrm{SiMoA}^{\mathrm{TM}}\right)$ technology and digital ELISA signal detection, has been developed. This technology enables detection of lower concentrations of proteins than with conventional tests such as microplate ELISA assays; the detection threshold is generally 100-fold lower or more, compared with current analog methods [28, 29].

The aim of this study was to assess the analytical performance of this new IFN $\gamma$ immunoassay prototype based on SiMoA technology and to compare it with the performance of the QFT-Plus IFN $\gamma$ ELISA kit. In particular, we investigated whether the SiMoA IFN $\gamma$ assay could improve the clinical interpretation of samples collected using QFT-Plus tubes and classified as "indeterminate" and "uncertain" using the QFT IFN $\gamma$ ELISA kit.

\section{MATERIALS AND METHODS}

\section{QFT-TB Gold Plus assay}

The QuantiFERON-TB Gold Plus (QFT-Plus) assay (Qiagen) measures cell-mediated immune responses to two different peptide cocktails (TB1 and TB2, see below) from two $M$. tuberculosis proteins (ESAT-6 and CFP10). The assay is performed in two stages. In the first stage, blood samples are transferred to the laboratory in collection tubes containing the peptide cocktail where they are incubated at $37^{\circ} \mathrm{C}$ for $16-24$ hours. In the second stage, the plasma is harvested and the secreted IFN $\gamma$ is measured with the QFT ELISA kit in a $50 \mu \mathrm{L}$ aliquot.

The routine QFT-Plus assay was performed according to the manufacturer's recommendations except the whole blood samples that had been collected in lithium heparin tubes could be received up to 24 hours after collection at the Pitié-Salpêtrière Hospital in the Cellular and Tissue Immunology Laboratory, whereas the manufacturer recommends up to $16 \mathrm{~h}$. For each patient, blood samples were transferred into the four specialized collection QFT-Plus tubes:

- a negative control tube, i.e., NIL (without antigen);

- a positive control tube, i.e., mitogen (MIT; PHA);

- a tube containing ESAT-6 and CFP10 long peptides, i.e., TB antigen 1 (TB1);

- a tube containing ESAT-6, CFP10 short and long peptides, i.e., TB antigen 2 (TB2).

A log-log standard curve was generated by plotting the log of the mean optical density (OD) on the y-axis against the $\log$ of the IFN $\gamma$ concentration of the four standards $(0,0.25$, 
Table 1

Rules for interpreting the results from the QuantiFERON-TB Gold Plus assay.

\begin{tabular}{|c|c|c|c|}
\hline \multirow[t]{2}{*}{ Categories of results } & \multirow[t]{2}{*}{ MIT-NIL } & \multicolumn{2}{|l|}{$\delta \mathrm{TB} 1$ and $\delta \mathrm{TB2}$} \\
\hline & & $\begin{array}{l}\text { Manufacturer's } \\
\text { recommendation }\end{array}$ & Uncertainty categories \\
\hline Indeterminate & $<0.5 \mathrm{IU} / \mathrm{mL}$ & Not interpretable & Not interpretable \\
\hline Negative & $\geq 0.5 \mathrm{IU} / \mathrm{mL}$ & $<0.35 \mathrm{IU} / \mathrm{mL}$ & $<0.2 \mathrm{IU} / \mathrm{mL}$ \\
\hline Uncertain negative & $\geq 0.5 \mathrm{IU} / \mathrm{mL}$ & Not considered & {$\left[0.2-0.35\left[\mathrm{IU} / \mathrm{mL}^{\mathrm{a}}\right.\right.$} \\
\hline Uncertain positive & $\geq 0.5 \mathrm{IU} / \mathrm{mL}$ & Not considered & {$\left[0.35-0.7\left[\mathrm{IU} / \mathrm{mL}^{\mathrm{a}}\right.\right.$} \\
\hline Positive & All & $\geq 0.35 \mathrm{IU} / \mathrm{mL}^{\mathrm{a}}$ & $\geq 0.7 \mathrm{IU} / \mathrm{mL}^{\mathrm{a}}$ \\
\hline
\end{tabular}

MIT: positive control tube or mitogen; NIL: negative control tube: $\delta \mathrm{TB} 1$ : TB1-NIL; $\delta \mathrm{TB} 2$ : TB2-NIL.

a $\delta \mathrm{TB} 1$ or $\delta \mathrm{TB} 2>25 \%$ of NIL.

1.0, and $4.0 \mathrm{IU} / \mathrm{mL}$ ) supplied in the kit on the $x$-axis. The line of best fit for the standard curve was then determined with regression analysis and used to determine the IFN $\gamma$ concentration in IU/mL for each of the tested plasma samples, using the OD value of each sample. The results were calculated as MIT minus NIL and TB1 (or TB2) minus

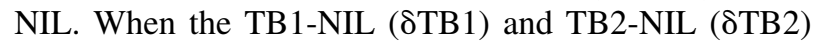
results were discordant, the highest value was taken into account for interpretation. The results were interpreted as summarized in table 1.

\section{SiMoA IFN y immunoassay prototype}

The SiMoA IFN $\gamma$ immunoassay prototype is a fully automated three-step sandwich immunoassay that quantifies IFN $\gamma$ in plasma and cell culture supernatants using the HD-1 Analyzer. In this assay, the IFN $\gamma$ is captured onto antibody-coated paramagnetic beads and detected with a biotin-labeled antibody and an enzyme-conjugated streptavidin. The individual beads are then isolated and sealed in arrays of femtoliter-sized wells in the presence of a fluorogenic enzyme substrate. The fluorescence emitted is captured by a charged coupled device (CCD) camera, allowing the number of wells containing an enzymelabelled bead and the level of emitted fluorescence to be ascertained. Both the fraction of beads associated with at least one enzyme and the fluorescence intensity from each well are determined, enabling the instrument to detect ultra-low IFN $\gamma$ concentrations (digital readout mode). The assay was calibrated with native IFN $\gamma$ antigen obtained by stimulation of peripheral blood mononuclear cells (PBMCs) and diluted in the sample diluent. Standards were calibrated in IU/mL, based on determinations with the QFT ELISA assay. The calibration curve was established using seven standards tested in duplicate $(0,0.0023,0.0056$, $0.029,0.13,0.61$, and $2.34 \mathrm{IU} / \mathrm{mL}$ ) using a four-parameter logistic (4PL) regression model [30]. Two duplicate control samples were included; one with a concentration within the digital range and the other with a concentration within the analog range for the SiMoA IFN $\gamma$ assay.

The carboxy-paramagnetic microbeads $(2.7-\mu \mathrm{m}$, provided by Agilent Technologies) coated with a mouse monoclonal anti-human IFN $\gamma$ antibody (developed by bioMérieux) were mixed with $75 \mu \mathrm{L}$ of the prediluted sample (1/4) and incubated for 15 minutes. An additional dilution (1/20) was analyzed when saturation of TB1 or TB2 occurred. The antibody-coated beads were diluted to obtain a concentration of $2 \times 10^{7}$ beads $/ \mathrm{mL}$ in Tris buffered saline with $0.05 \%$ tween 20 and $0.05 \%$ bovine serum albumin (BSA).
The capture microbeads were collected into a pellet using a magnet, washed and then incubated for five minutes with biotinylated anti-human IFN $\gamma$-detector monoclonal antibody (also developed by bioMérieux) at $0.1 \mu \mathrm{g} / \mathrm{mL}$ in phosphate-buffered saline containing $0.05 \%$ tween 20 (PBST) and $0.05 \%$ BSA. After pelleting and washing, the beads were incubated with streptavidin- $\beta$-galactosidase ( $\mathrm{S} \beta \mathrm{G}$; enzymatic conjugate) compound for five minutes. The $S \beta G$ compound was prepared at bioMérieux by covalent conjugation of purified streptavidin (Thermo Scientific) and $\beta \mathrm{G}$ (Sigma), and diluted to $150 \mathrm{ng} / \mathrm{mL}$ in PBST and $0.05 \%$ BSA. The beads were then pelleted and washed and finally incubated with the fluorogenic substrate, resorufin $\beta$-D-galactopyranoside (RGP). The HD-1 analyzer processed the substrate incubation, bead transfer onto the disk and the CCD camera reading and image acquisition in about three minutes.

\section{Assessment of assay reproducibility and limits of quantification}

The reproducibility of the SiMoA IFN $\gamma$ and QFT IFN $\gamma$ ELISA assays was assessed using samples that were within their specific detection ranges: from 0.0023 to $2.34 \mathrm{IU} / \mathrm{mL}$ and from $0.065 \mathrm{IU} / \mathrm{mL}$ (LOD) to $10.0 \mathrm{IU} / \mathrm{mL}$ (extrapolated highest standard), respectively [31].

The reproducibility of the QFT ELISA assay was assessed using 13 blood samples that were tested in duplicate over three days. Two technicians performed the assays in one laboratory, using the same QFT ELISA assay batch $(n=12$ for each sample). The limit of quantification (LOQ) at $20 \%$ $\mathrm{CV}$ was estimated using concentrations of the 13 blood samples ranging from $0.02 \mathrm{IU} / \mathrm{mL}$ to $4.0 \mathrm{IU} / \mathrm{mL}$, with eight of the samples in the low range $(0.02-0.37 \mathrm{IU} / \mathrm{mL})$.

The reproducibility of the SiMoA IFN $\gamma$ assay was performed using one HD-1 instrument. Seven plasma samples and two controls in duplicate (one digital and one analog) with concentrations ranging from 0.02 to $1.0 \mathrm{IU} / \mathrm{mL}$ were tested twice a day for three days ( $n=12$ for each sample). Five of the samples, obtained by dilution in the sample diluent, were used specifically to assess the assay LOQ at $20 \% \mathrm{CV}$.

\section{Linearity of the SiMoA IFN $\gamma$ and QFT assays}

To assess the linearity of the SiMoA IFN $\gamma$ assay two plasma samples, containing 0.64 and $2.51 \mathrm{IU} / \mathrm{mL}$ of IFN $\gamma$, were serially diluted with the sample diluent from $3 / 4$ to $1 / 20$ for sample $\mathrm{A}$, and from $3 / 5$ to $1 / 20$ for sample $\mathrm{B}$, 
Table 2

Origin of the 151 samples assessed with the SiMoA IFN $\gamma$ assay by classification based on QFT IFN $\gamma$ ELISA results.

\begin{tabular}{|lllllll|}
\hline $\begin{array}{l}\text { Classification of } \\
\text { sample (N) }\end{array}$ & Total & $\begin{array}{l}\text { Internal } \\
\text { medicine }\end{array}$ & $\begin{array}{l}\text { Rheumatology/ } \\
\text { gastroenterology }\end{array}$ & $\begin{array}{l}\text { Occupational } \\
\text { medicine }\end{array}$ & Others & $\begin{array}{l}\text { Lymphocyte count } \\
\text { available }\end{array}$ \\
\hline Positive & $35^{\text {a }}$ & 6 & 2 & 5 & 20 & 10 \\
\hline Negative & 30 & 5 & 6 & 6 & 13 & 14 \\
\hline Uncertain positive & $31^{\mathrm{a}}$ & 8 & 3 & 6 & 12 & 11 \\
\hline Uncertain negative & $25^{\mathrm{a}}$ & 4 & 4 & 4 & 11 & 10 \\
\hline Indeterminate & 30 & 10 & 5 & 0 & 71 & $62(41 \%)$ \\
\hline Total & 151 & 33 & 20 & 21 & & 17 \\
\hline
\end{tabular}

${ }^{\text {a }}$ Information missing for two samples in each category.

${ }^{\mathrm{b}}$ From infectious medicine, pulmonology, neurology, ophthalmology, nephrology and organ transplantation departments.

giving concentrations from $0.48 \mathrm{IU} / \mathrm{mL}$ to $0.032 \mathrm{IU} / \mathrm{mL}$ and from $1.51 \mathrm{IU} / \mathrm{mL}$ to $0.13 \mathrm{IU} / \mathrm{mL}$, respectively. Each dilution was tested in duplicate to assess the linearity of SiMoA IFN $\gamma$ assay. The IFN $\gamma$ concentrations were determined using an in-house standard curve.

We did not assess the linearity of the QFT IFN $\gamma$ ELISA here because the manufacturer had documented its linearity previously [31].

\section{Samples tested}

A total of 1,717 fresh blood samples from hospitalized or consulting patients from three hospitals in Paris, France (Pitié-Salpêtrière, Saint-Antoine and Tenon Hospitals), were assessed routinely in our laboratory using the QFTPlus assay from 19 June to 10 October 2017. There were 1,387 negative $(81 \%), 188$ positive $(11 \%), 50$ uncertain negative (3\%), 56 uncertain positive $(3 \%)$, and 36 indeterminate (2\%) samples. A total of 151 of these samples that were frozen after the QFT IFN $\gamma$ ELISA test were later assessed with the SiMoA IFN $\gamma$ assay: 30 negative, 25 uncertain negative, 35 positive, 31 uncertain positive, and 30 indeterminate samples. The samples were a convenience selection of samples that had a sufficient volume for the SiMoA IFN $\gamma$ assay to obtain about 30 in each category. The majority of the samples came from hospitalized patients and 21 were from healthcare professionals (table 2). Lymphocyte counts were available for $41 \%$ of the samples.

These samples were used to assess if the higher sensitivity of the SiMoA IFN $\gamma$ assay could confirm the positive and negative results and improve the clinical interpretation of samples classified as indeterminate or uncertain positive or negative based on the results from the QFT IFN $\gamma$ ELISA assay. The indeterminate samples were mainly from immunosuppressed patients, with a MIT-NIL $<0.5 \mathrm{IU} / \mathrm{mL}$. The thresholds for the negative and positive $\delta \mathrm{TB} 1$ and $\delta \mathrm{TB} 2$ samples were $<0.2 \mathrm{IU} / \mathrm{mL}$ and $>0.7 \mathrm{IU} / \mathrm{mL}$, respectively. The results for the uncertain negative and uncertain positive samples fell into the uncertainty zones around the cutoff of $0.35 \mathrm{IU} / \mathrm{mL} ; 0.2$ to $0.35 \mathrm{IU} / \mathrm{mL}$ and 0.35 to $0.7 \mathrm{IU} / \mathrm{mL}$, respectively [27].

\section{Statistical analysis}

Analyses were performed using the GraphPad Prism (version 7.03), SAS-Add in (version 4.3), and Analyse-it (version 3.70) software. Passing and Bablok regression analysis, a nonparametric statistical method, was used to estimate the agreement between the assays and detect any systematic bias between them [32].

\section{RESULTS}

\section{Analytical performance of the SiMoA IFN $\gamma$ assay and the QFT IFN $Y$ ELISA}

\section{Reproducibility and limits of quantification}

The intra-assay CVs for the SiMoA IFN $\gamma$ assay were below $4 \%$ for samples ranging from 0.045 to $1.037 \mathrm{IU} / \mathrm{mL}$ compared with CVs from $4.4 \%$ to $14.1 \%$ for the QFT ELISA assay for samples ranging from 0.595 to $3.998 \mathrm{IU} / \mathrm{mL}$ (table 3). The inter-assay $\mathrm{CV}$ s for the SiMoA IFN $\gamma$ assay ranged from $3.7 \%$ to $8.2 \%$ compared with from $10.5 \%$ to $21.3 \%$ for the QFT ELISA.

The precision profiles for both assays were plotted using the results for the lowest concentration samples tested in the repeatability study to determine the LOQ, corresponding to $20 \%$ of the CV (figure 1). The LOQ for the QFT ELISA was $0.169 \mathrm{IU} / \mathrm{mL}$ compared with $0.002 \mathrm{IU} / \mathrm{mL}$ for the SiMoA IFN $\gamma$ assay.

\section{Linearity of the SiMoA IFN $\gamma$ assay}

For the assessment of the linearity of the SiMoA IFN $\gamma$ assay the recovery rate ranged from $99.2 \%$ to $115.7 \%$ for sample A (initial IFN $\gamma$ concentration $0.64 \mathrm{IU} / \mathrm{mL}$ ) and from $103.3 \%$ to $111.0 \%$ for sample B (initial IFN $\gamma$ concentration $2.51 \mathrm{IU} / \mathrm{mL}$ ), with slopes and a $R^{2}$ close to 1.0 for both samples (figure 2).

\section{Verification of the metrological traceability between the QFT IFNY ELISA and SiMoA IFNY assay}

The correlation of the results from the SiMoA and QFT IFN $\gamma$ ELISA assays was assessed using the 35 positive samples, i.e., where $\delta \mathrm{TB} 1$ and/or $\delta \mathrm{TB} 2$ were $\geq 0.7 \mathrm{IU} / \mathrm{mL}$, to ensure that the poorer precision of the QFT IFN $\gamma$ ELISA assay in the low range of concentrations would not bias the results. The IFN $\gamma$ concentrations obtained with SiMoA IFN $\gamma$ assay were, on average, $17 \%$ higher than those obtained with the QFT ELISA assay for $\delta$ TB1 and 24\% higher for $\delta \mathrm{TB} 2$ (95\% CI: 0.99-1.42 and 1.01-1.41, respectively). The correlation equations were $y=1.17 x+0.16$ for 
Table 3

Reproducibility of QFT and SiMoA IFN $\gamma$ assays.

\begin{tabular}{|c|c|c|}
\hline IFN $\gamma$ sample mean $(\mathrm{IU} / \mathrm{mL})$ & Intra-assay CV (\%) & Inter-assay CV (\%) \\
\hline \multicolumn{3}{|l|}{ QFT IFN $\mathrm{ELISA}$ assay $(n=12)$} \\
\hline 0.595 & 4.4 & 10.5 \\
\hline 1.471 & 14.1 & 21.3 \\
\hline 2.211 & 12.0 & 12.4 \\
\hline 3.998 & 7.2 & 11.6 \\
\hline \multicolumn{3}{|l|}{ SiMoA IFN $\operatorname{IFssay}(n=12)$} \\
\hline 0.045 & 2.7 & 8.2 \\
\hline 0.080 & 3.2 & 3.7 \\
\hline 0.484 & 3.7 & 4.5 \\
\hline 1.037 & 3.4 & 7.4 \\
\hline
\end{tabular}

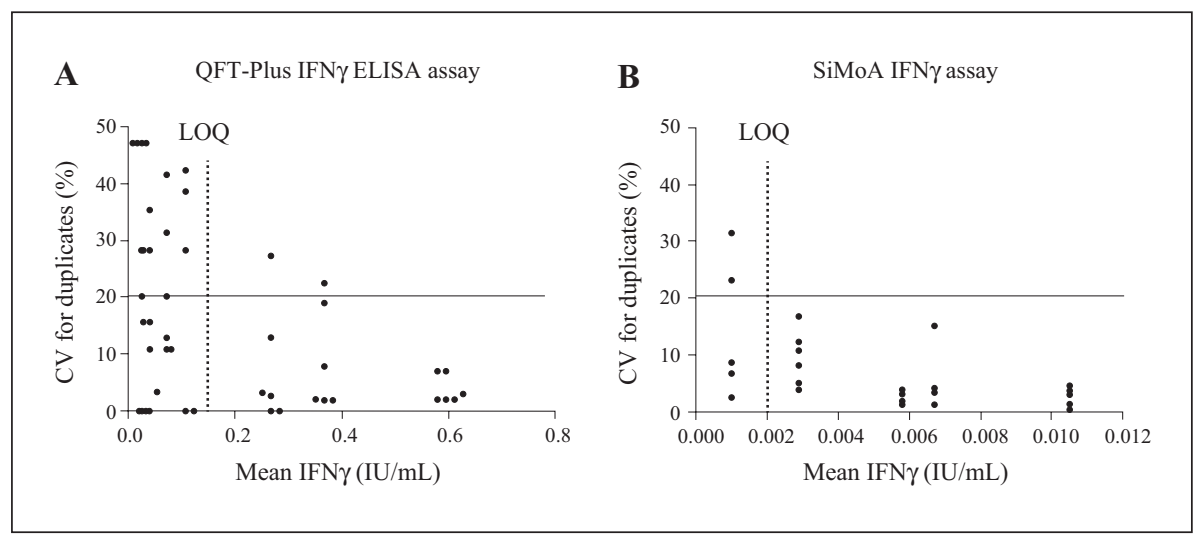

Figure 1

Limits of quantification (LOQ) for (A) QFT IFN $\gamma$ ELISA and (B) SiMoA IFN $\gamma$ assays determined using the 20\% CV for the lowest concentration samples in the repeatability study.

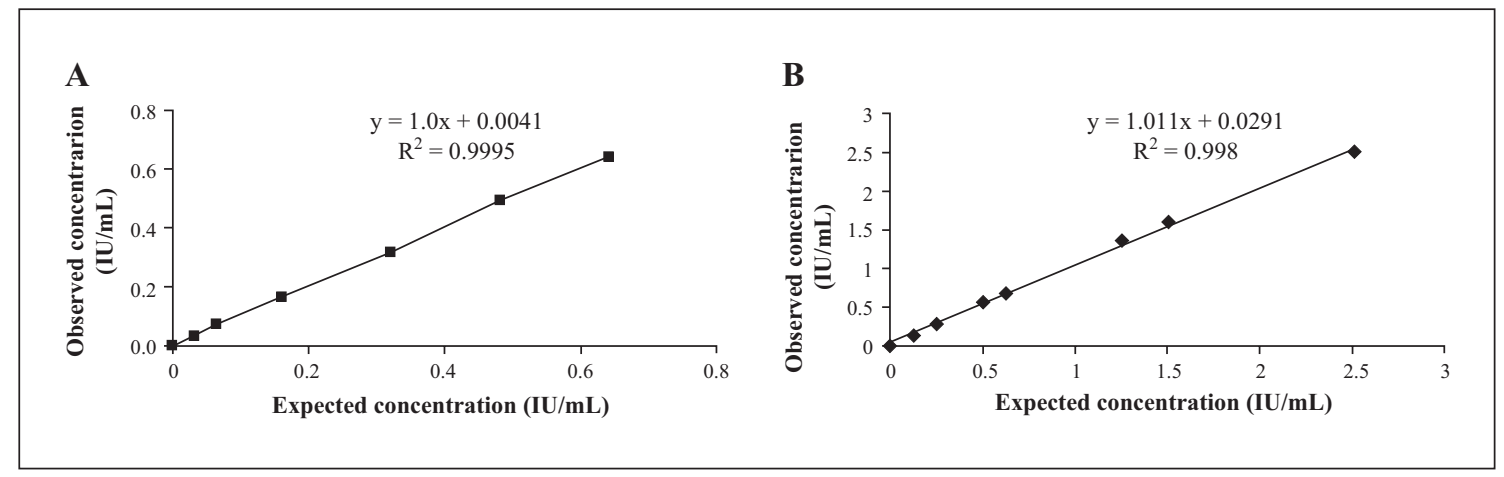

Figure 2

Linear regression curves with regression equations and $R^{2}$ values for SiMoA IFN $\gamma$ assay for (A) sample A, initial INF $\gamma$ concentration $0.64 \mathrm{IU} / \mathrm{mL}$ and (B) sample B, initial INF $\gamma$ concentration $2.51 \mathrm{IU} / \mathrm{mL}$.

$\delta \mathrm{TB} 1$ and $y=1.24 x+0.09$ for $\delta \mathrm{TB} 2$ (figure 3 ). The Pearson's correlation coefficient $R^{2}$ was 0.923 for both $\delta$ TB1 and $\delta \mathrm{TB} 2$.

\section{SiMoA IFN $\gamma$ assay results for nonpositive QFT-Plus results}

\section{Comparison of indeterminate results}

A total of 30 samples with indeterminate MIT-NIL results $(<0.5 \mathrm{IU} / \mathrm{mL})$ from the QFT-Plus assay were also analyzed with the SiMoA assay. The SiMoA assay results for the majority of NIL tubes were above the LOQ of $0.002 \mathrm{IU} / \mathrm{mL}$ (median value $0.026 \mathrm{IU} / \mathrm{mL}$, interquartile range [IQR] 0.008 to $0.055 \mathrm{IU} / \mathrm{mL}$ ), compared with none of the QFT
ELISA results (median value $0.055 \mathrm{IU} / \mathrm{mL}$, IQR 0.033 to $0.080 \mathrm{IU} / \mathrm{mL}$ ) (figure $4 A$ ). Only two of the samples were not measurable by the SiMoA assay, but they were both detectable and lower than the LOQ $(0.0014 \mathrm{IU} / \mathrm{mL})$. The median MIT results from the SiMoA and the QFT assays were $0.393 \mathrm{IU} / \mathrm{mL}$ with IQR 0.198 to $0.690 \mathrm{IU} / \mathrm{mL}$ and $0.230 \mathrm{IU} / \mathrm{mL}$ with IQR 0.089 to $0.300 \mathrm{IU} / \mathrm{mL}$, respectively (figure $4 B$ ). The MIT-NIL values for the SiMoA assay were significantly different from those for the QFT IFNy ELISA assay, resulting in a MIT-NIL value $>0.5 \mathrm{IU} / \mathrm{mL}$ for $11 / 30$ samples making interpretation possible according to the manufacturer's recommendations (table 1; figure 4C). The lymphocyte count was within the normal range (1,5004,000 lymphocytes $/ \mathrm{mm}^{3}$ ) for three of the 17 QFT-Plus 


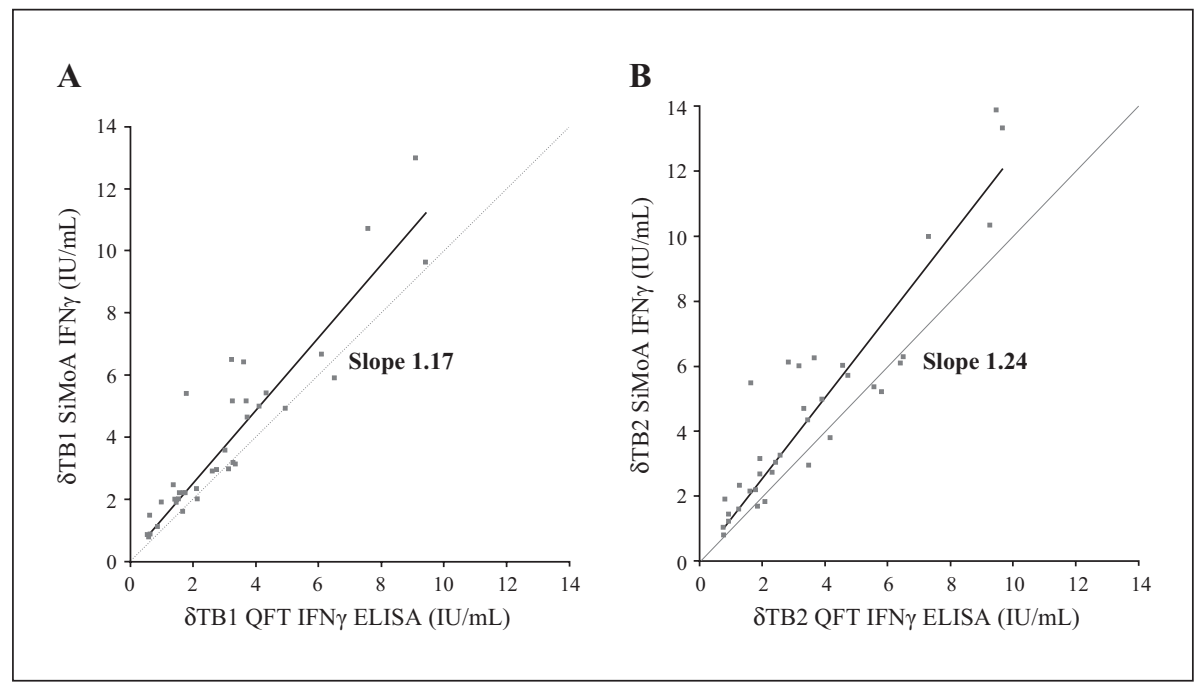

Figure 3

Passing-Bablok correlation between (A) $\delta$ TB1 and (B) $\delta T B 2$ IFN $\gamma$ concentrations (IU/mL) obtained with the QFT IFN $\gamma$ ELISA and SiMoA IFN $\gamma$ assays using 35 positive blood samples ( $\delta \mathrm{TB} 1$ or $\delta \mathrm{TB} 2 \geq 0.7 \mathrm{IU} / \mathrm{mL}$, as determined with the QFT IFN $\gamma$ ELISA assay). The gray dashed line indicates $100 \%$ agreement (slope $=1.00$ )

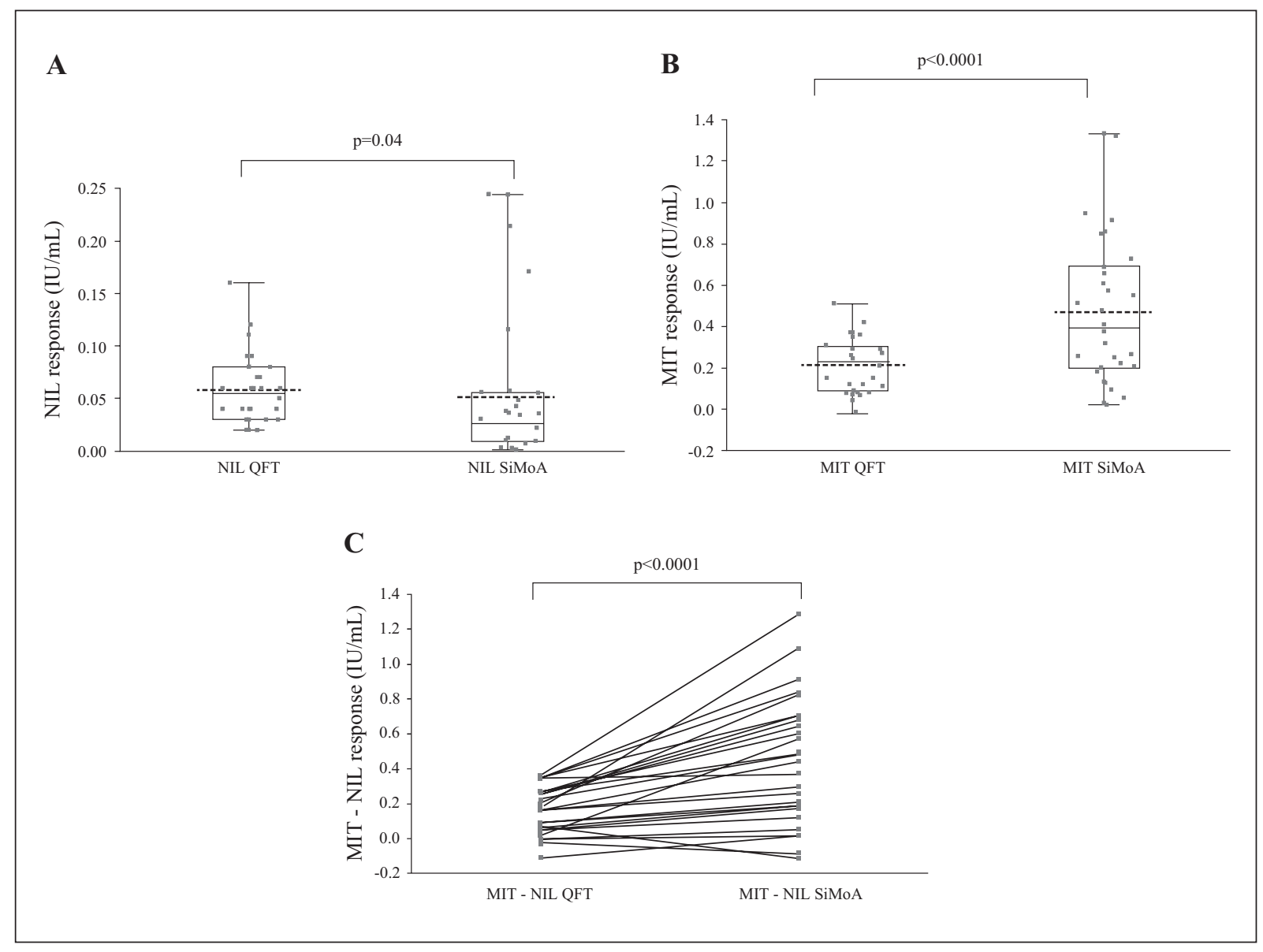

Figure 4

Box and whisker plots of (A) NIL and (B) MIT responses (IU/mL) with the QFT ELISA and SiMoA IFN $\gamma$ assays for samples with indeterminate results with the QFT-Plus assay $(n=30)$ showing median, interquartile range and the minimum and maximum values. $P$ values were calculated by Wilcoxon test. The dashed lines denote the means. (C) Pairwise comparison for the MIT-NIL results from the QFT-Plus and SiMoA IFN $\gamma$ assays for the 30 samples with indeterminate results with the QFT-Plus assay.

indeterminate samples for which lymphocyte counts were available. For the remaining 14 , the counts were below the normal range (mean: 698 lymphocytes $/ \mathrm{mm}^{3}$, SD: 332 lymphocytes $/ \mathrm{mm}^{3}$ ). No link between lymphopenia and the MIT-NIL value was observed.
The $\delta T B 1$ and $\delta T B 2$ results for the 11/30 samples with MIT-NIL values $>0.5 \mathrm{IU} / \mathrm{mL}$ in the SiMoA assay (maximum $=0.027$ and 0.016 , respectively) were all below the uncertain positivity thresholds of $0.2 \mathrm{IU} / \mathrm{mL}$ and $0.35 \mathrm{IU} / \mathrm{mL}$ for the SiMoA and QFT IFN $\gamma$ ELISA assays, 
Table 4

Impact of lower MIT-NIL thresholds with the SiMoA assay on the classification of 30 samples from the QFT-Plus "indeterminate" category.

\begin{tabular}{|llll|}
\hline MIT-NIL threshold & Indeterminate & Interpretable & $\begin{array}{l}\text { Interpretation based } \\
\text { on } \delta \text { TB1 and } \delta \text { TB2 }\end{array}$ \\
\hline$>0.5 \mathrm{IU} / \mathrm{mL}$ & $19 / 30$ & $11 / 30$ & $\begin{array}{l}\text { Not considered } \\
\text { Negative }\end{array}$ \\
\hline$>0.35 \mathrm{IU} / \mathrm{mL}$ & $15 / 30$ & $15 / 30$ & $\begin{array}{l}\text { Not considered } \\
\text { Negative }\end{array}$ \\
\hline$>0.2 \mathrm{IU} / \mathrm{mL}$ & & $20 / 30$ & $\begin{array}{l}\text { Not considered } \\
\text { Negative }\end{array}$ \\
\hline$>0.1 \mathrm{IU} / \mathrm{mL}$ & $10 / 30$ & $25 / 30$ & $\begin{array}{l}\text { Not considered } \\
\text { Negative }\end{array}$ \\
\hline
\end{tabular}

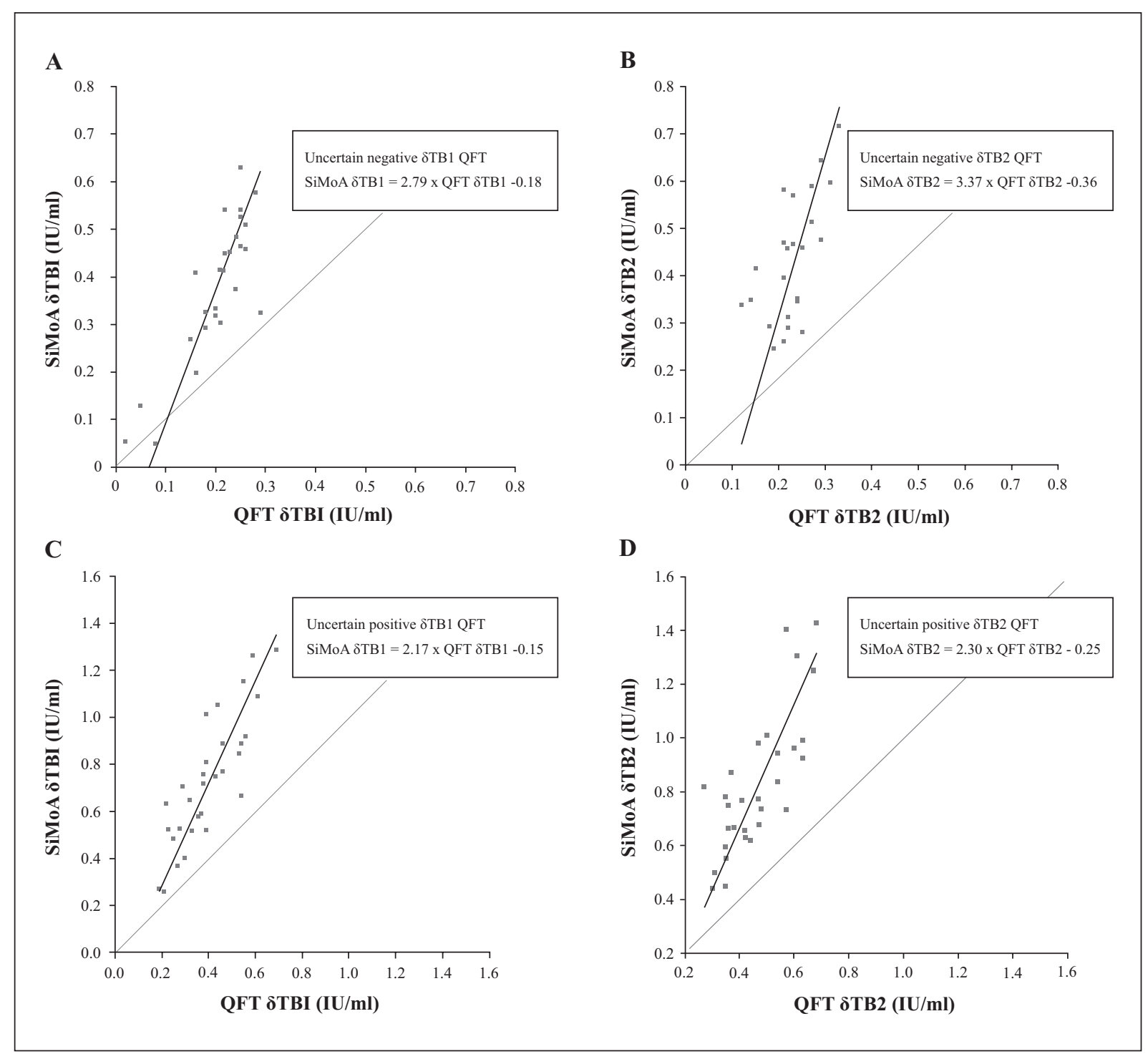

Figure 5

Passing-Bablok regression analyses of results from the QFT-Plus $\delta \mathrm{TB} 1$ and $\delta \mathrm{TB} 2$ versus SiMoA $\delta \mathrm{TB} 1$ and $\delta \mathrm{TB} 2$. (A) QFT-Plus $\delta \mathrm{TB} 1$ versus SiMoA $\delta$ TB1 and (B) QFT-Plus $\delta$ TB2 versus SiMoA $\delta$ TB2 using 25 uncertain negative blood samples ( $\delta$ TB1 or $\delta$ TB2 with the QFT assay [0.2-0.35[ IU/mL). (C) QFT-Plus $\delta \mathrm{TB} 1$ versus SiMoA $\delta \mathrm{TB} 1$ and (D) QFT-Plus $\delta \mathrm{TB} 2$ versus SiMoA $\delta \mathrm{TB} 2$ using 31 uncertain positive blood samples $(\delta \mathrm{TB} 1$ or $\delta \mathrm{TB} 2$ with the QFT-Plus assay $[0.35-0.7[\mathrm{IU} / \mathrm{mL})$. The gray line indicates $100 \%$ agreement.

respectively and they were interpreted as negative. Since the LOQ for the SiMoA assay is lower than that for the QFT ELISA, a MIT-NIL threshold lower than $0.5 \mathrm{IU} / \mathrm{mL}$ could be considered. The results with lower MIT-NIL thresholds on the clinical interpretation of the indeterminate samples are summarized in table 4. The lowest MIT-NIL threshold, $>0.1 \mathrm{IU} / \mathrm{mL}$, enabled the results for 25 of the 30 indeterminate samples to be interpreted; all were negative. Four of the five samples that remained indeterminate had high NIL values (data not shown). 
Table 5

Classification of the samples based on (A) uncertainty categories and (B) QFT-Plus manufacturer's categories.

\begin{tabular}{|c|c|c|c|c|c|}
\hline \multirow[t]{2}{*}{ A. Uncertainty categories } & \multicolumn{4}{|c|}{ QFT IFN $\gamma$ ELISA } & \multirow[t]{2}{*}{ Total } \\
\hline & $\begin{array}{l}\text { Negative } \\
\text { ( } \delta \mathrm{TB1} \text { or } \\
\delta \mathrm{TB2} \\
<0.2 \mathrm{IU} / \mathrm{ml})\end{array}$ & $\begin{array}{l}\text { Uncertain } \\
\text { negative ( } \delta \mathrm{TB1} \\
\text { or } \delta \mathrm{TB} 2 \\
{[\mathbf{0 . 2 - 0 . 3 5}[\mathrm{IU} / \mathrm{ml})}\end{array}$ & $\begin{array}{l}\text { Uncertain } \\
\text { positive }(\delta \mathrm{TB} 1 \text { or } \\
\delta \mathrm{TB2} \\
{[0.35-0.7[\mathrm{IU} / \mathrm{ml})}\end{array}$ & 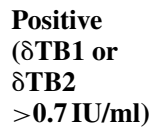 & \\
\hline \multicolumn{6}{|l|}{ SiMoA IFN } \\
\hline Negative ( $\delta \mathrm{TB} 1$ or $\delta \mathrm{TB} 2<0.2 \mathrm{IU} / \mathrm{ml}$ ) & 28 & 0 & 0 & 0 & 28 \\
\hline Uncertain negative $(\delta \mathrm{TB} 1$ or $\delta \mathrm{TB} 2[0.2-0.35[\mathrm{IU} / \mathrm{ml})$ & 1 & 7 & 0 & 0 & 8 \\
\hline Uncertain positive ( $\delta \mathrm{TB} 1$ or $\delta \mathrm{TB} 2[0.35-0.7[\mathrm{IU} / \mathrm{ml}$ ) & 1 & 17 & 8 & 0 & 26 \\
\hline Positive $(\delta \mathrm{TB} 1$ or $\delta \mathrm{TB} 2>0.7 \mathrm{IU} / \mathrm{ml}$ ) & 0 & 1 & 23 & 35 & 59 \\
\hline Total & 30 & 25 & 31 & 35 & 121 \\
\hline \multirow[t]{2}{*}{ B. QFT-Plus categories } & \multicolumn{3}{|c|}{ QFT IFN $\gamma$ ELISA } & & \multirow[t]{2}{*}{ Total } \\
\hline & \multicolumn{2}{|c|}{$\begin{array}{l}\text { Negative ( } \delta \text { TB1 or } \\
\delta \text { TB2 }<0.35 \text { IU/ml) }\end{array}$} & $\begin{array}{l}\text { Positive ( } \delta \text { TB1 or } \\
\delta \text { TB2 } \geq \mathbf{0 . 3 5} \mathrm{IU} / \mathrm{ml})\end{array}$ & & \\
\hline \multicolumn{6}{|l|}{ SiMoA IFNy } \\
\hline Negative ( $\delta \mathrm{TB} 1$ or $\delta \mathrm{TB} 2<0.35 \mathrm{IU} / \mathrm{ml}$ ) & \multicolumn{2}{|l|}{36} & 0 & & 36 \\
\hline Positive $(\delta \mathrm{TB} 1$ or $\delta \mathrm{TB} 2 \geq 0.35 \mathrm{IU} / \mathrm{ml})$ & \multicolumn{2}{|l|}{19} & \multicolumn{2}{|l|}{66} & 85 \\
\hline Total & \multicolumn{2}{|l|}{55} & \multicolumn{2}{|l|}{66} & 121 \\
\hline
\end{tabular}

The numbers of concordant samples for each classification are indicated in bold.

Comparison of uncertain positive, uncertain negative, and negative results

Passing-Bablok regression analyses were used to compare the results for samples that were classified as uncertain (positive and negative) with the QFT-Plus assay with those from the SiMoA assay (figure 5). We also used the QFTPlus manufacturer's criteria for the uncertainty categories to compare the interpretation of the results from both assays.

Unlike the analyses with positive samples, where the Passing-Bablok analyses gave slopes of 1.17 and 1.24 for the $\delta$ TB1 and $\delta$ TB2 results, respectively, higher slopes were observed with the uncertain categories (figures 3 and $5)$. In these analyses the slopes for the $\delta \mathrm{TB} 1$ and $\delta \mathrm{TB} 2$ results for uncertain negative samples were 2.79 and 3.37, respectively, and 2.17 and 2.30, respectively, for uncertain positive samples (figure 5).

When the uncertainty thresholds and the QFT-Plus manufacturer's thresholds were used to interpret the results, discordant results were observed for 43 and 19 samples, respectively (table 5). The $\delta \mathrm{TB} 1$ and $\delta \mathrm{TB} 2 \mathrm{SiMoA}$ assay results were classified in a higher category than the QFTPlus assay results for all 19 discordant samples, using the manufacturer's thresholds (data not shown).

Passing-Bablok regression analyses were not performed for the negative samples because most of the QFT $\delta$ TB1 and $\delta \mathrm{TB} 2$ were close to 0 or negative.

\section{DISCUSSION}

The WHO recommends screening for LTBI in certain atrisk populations [3]. Biological exploration with TB IGRA assays is an important element for the diagnosis of LTBI since there are no clinical symptoms. However, the results for transplanted patients or individuals living with HIV may be indeterminate due to lymphopenia or immunosuppressive therapy [23, 33-35]. A more sensitive test, such as the SiMoA IFN $\gamma$ assay, could provide more definite results confirming or refuting the diagnosis of LTBI in these patients.

The LOQ for the SiMoA IFN $\gamma$ assay was lower than that for the QFT ELISA assay $(0.002 \mathrm{IU} / \mathrm{mL}$ versus $0.169 \mathrm{IU} / \mathrm{mL})$ confirming that the IFN $\gamma$ assay based on digital SiMoA technology is about 100-fold more sensitive than the QFT ELISA assay.

We obtained inter-assay CVs ranging from $10.5 \%$ to $21.3 \%$ for samples containing IFN $\gamma$ concentrations ranging from 0.6 to $4.0 \mathrm{IU} / \mathrm{mL}$ for the QFT ELISA, which is similar to those indicated in the manufacturer's package insert and those previously reported; inter-assay CVs of $13 \%$ around an individual mean of $\pm 0.47 \mathrm{IU} / \mathrm{mL}$ for all values (irrespective of the initial IFN $\gamma$ value) and CVs of $30 \%$ around an individual mean of $\pm 0.26 \mathrm{IU} / \mathrm{ml}$ for individuals with an initial borderline IFN $\gamma$ response (in the range of 0.25 $0.80 \mathrm{IU} / \mathrm{mL}$ ) $[26,27]$. The inter-assay CVs were smaller for the SiMoA IFN $\gamma$ assay, ranging from $3.7 \%$ to $8.2 \%$ for samples containing IFN $\gamma$ concentrations ranging from 0.05 to $1.04 \mathrm{IU} / \mathrm{mL}$. This variability for samples with low IFN $\gamma$ concentrations ranging from 0.01 to $0.40 \mathrm{IU} / \mathrm{mL}$ with the QFT assay has an important impact on the clinical interpretation of assay results and therefore the management of these patients. In addition, the manufacturer recommends only one assay per sample, which could result in a higher risk of false positive and negative results due to the poor precision. We found good agreement for the clinical interpretation of results from the two assays, when we checked the metrological traceability of the SiMoA assay to the QFT IFN $\gamma$ ELISA assay by regression analysis using the 35 positive samples, i.e., with a $\delta \mathrm{TB} 1$ and/or $\delta \mathrm{TB} 2$ $\geq 0.7 \mathrm{IU} / \mathrm{mL}$.

In clinical practice, samples that have either an uncertain positive, uncertain negative or indeterminate result are retested with the T-SPOT-TB assay, which is a more sensitive TB IGRA assay than the QFT assay, to attempt to provide a better clinical interpretation [36]. The advantage of the T-SPOT-TB assay is that a standard number of PBMCs is used, which can correct for a patient's immune 
status, but a second blood sample has to be taken, which can be inconvenient for both clinicians and patients. The SiMoA IFN $\gamma$ assay results, using the original frozen samples, were consistent with the T-SPOT-TB assay results using a second set of blood samples from 6/14 patients (data not shown). Among the remaining eight samples, four that gave uncertain positive results with the QFT assay and negative results with T-SPOT-TB assay, were positive with the SiMoA IFN $\gamma$ assay. This may be explained by the higher sensitivity of the SiMoA IFN $\gamma$ assay and its measurement precision at low IFN $\gamma$ concentrations, since in samples with low levels of secreted IFN $\gamma$, the SiMoA technology enables distinguishing between no response and a weak response to the TB antigens. Thus, the SiMoA IFN $\gamma$ assay could help to provide a clearer interpretation to guide clinical decisions with respect to LTBI without the need for a second blood sample. Although, it has been reported that IGRA assays are sensitive to blood lymphocyte counts, we observed no link between lymphopenia and MIT-NIL values, although lymphocyte counts were only available for $41 \%$ of the samples [34, 37, 38].

The main limitation of this study relates to heterogeneity of the patient population since the cohort included both immunosuppressed patients, as well as immunocompetent patients and healthcare workers. However, this heterogeneity is representative of patients in a real-world setting that had undergone TB testing for a variety of reasons.

Our results suggest that the ultra-sensitive SiMoA IFN $\gamma$ assay could be a useful tool for the identification of true positive and negative samples among those giving indeterminate or uncertain results with the currently used TB IGRA assay and, therefore, allow appropriate clinical management of the patients. Future studies should be conducted on defined populations at risk, such as individuals living with HIV, patients receiving anti-TNF therapy and those who have undergone organ transplant, to confirm the potential advantages of using a more sensitive detection method such as the SiMoA IFN $\gamma$ assay.

Disclosure. Acknowledgments: the authors wish to thank members of the clinical cellular immunology team from the Pitié-Salpêtrière Hospital: Chrystelle Baude, Christine Chirat, David Derai, Jean-Luc Garnier, Muriel Legendre, Isabelle Mauger, Virginie Merere, Leticia Morel and Christophe Parizot and Corinne Perret from bioMérieux) for expert technical assistance. They also thank Guislaine Carcelain from PitiéSalpêtrière Hospital for IGRA assay training. They are grateful to Nathalie Renard, bioMérieux, for her critical review and corrections of the manuscript. They acknowledge medical writing and editorial services provided by Margaret Haugh (MediCom Consult, Villeurbanne, France) funded by bioMérieux. Financial support: the study was financed by the Assistance publiqueHôpitaux de Paris (AP-HP), Institut national de la santé et de la recherche médicale (INSERM), and Sorbonne universités. The study was also financed by bioMerieux. Conflicts of interests: the authors declare bioMérieux financial support (study and SiMoA reagents). Mylène Lesénéchal, Camille Pease Laure Allard and Céline Dragonetti are employed by bioMérieux.

\section{REFERENCES}

1. World Health Organization. Tuberculosis 2018. Available from: http://www.who.int/news-room/fact-sheets/detail/tuberculosis [last accessed 22 September 2018].
2. Centres for Disease Control and Prevention. Tuberculosis 2018. Available from: https://wwwnc.cdc.gov/travel/ yellowbook/2018/infectious-diseases-related-to-travel/tuberculosis [last accessed 22 September 2018].

3. World Health Organization. Guidelines on the management of latent tuberculosis infection. Spain: World Health Organization, 2015.

4. Houben RM, Dodd PJ. The global burden of latent tuberculosis infection: a re-estimation using mathematical modelling. PLoS Med 2016; 13: e1002152.

5. World Health Organization. Global tuberculosis report 2017. 2017. Available from: http://www.who.int/tb/publications/global_ report/gtbr2017_main_text.pdf [last accessed 22 September 2018].

6. Borisov AS, Bamrah Morris S, Njie GJ, et al. Update of recommendations for use of once-weekly isoniazid-rifapentine regimen to treat latent Mycobacterium tuberculosis infection. MMWR Morb Mortal Wkly Rep 2018; 67: 723-6.

7. Esmail H, Barry 3rd. CE, Young DB, Wilkinson RJ. The ongoing challenge of latent tuberculosis. Philos Trans R Soc Lond B Biol Sci 2014; 369: 20130437.

8. Huebner RE, Schein MF, Bass Jr. JB. The tuberculin skin test. Clin Infect Dis 1993; 17: 968-75.

9. Brock I, Munk ME, Kok-Jensen A, Andersen P. Performance of whole blood IFN-gamma; test for tuberculosis diagnosis based on PPD or the specific antigens ESAT-6 and CFP-10. Int J Tuberc Lung Dis 2001; 5: 462-7.

10. Centres for Disease Control and Prevention. Centennial: Koch's discovery of the tubercle bacillus. MMWR Morb Mortal Wkly Rep 1982; 31: 121-3.

11. Mazurek GH, LoBue PA, Daley CL, et al. Comparison of a whole-blood interferon gamma assay with tuberculin skin testing for detecting latent Mycobacterium tuberculosis infection. JAMA 2001; 286: 1740-7.

12. Meier T, Eulenbruch HP, Wrighton-Smith P, Enders G, Regnath T. Sensitivity of a new commercial enzyme-linked immunospot assay (T SPOT-TB) for diagnosis of tuberculosis in clinical practice. Eur J Clin Microbiol Infect Dis 2005; 24: 529-36.

13. Pai M, Denkinger CM, Kik SV, et al. Gamma interferon release assays for detection of Mycobacterium tuberculosis infection. Clin Microbiol Rev 2014; 27: 3-20.

14. Strickland N, Muller TL, Berkowitz N, et al. Characterization of Mycobacterium tuberculosis-specific cells using MHC class II tetramers reveals phenotypic differences related to HIV infection and tuberculosis disease. J Immunol 2017. doi: 10.4049/jimmunol.1700849 [Epub ahead of print].

15. Kobashi Y, Mouri K, Obase Y, Fukuda M, Miyashita N, Oka M. Clinical evaluation of QuantiFERON TB-2G test for immunocompromised patients. Eur Respir J 2007; 30: 945-50.

16. Aichelburg MC, Tittes J, Breitenecker F, Reiberger T, Kohrgruber N, Rieger A. Prognostic value of indeterminate IFN-gamma release assay results in HIV-1 infection. J Clin Microbiol 2012; 50: 2767-9.

17. Huson MA, Hoogendijk AJ, de Vos AF, Grobusch MP, van der Poll T. The impact of HIV infection on blood leukocyte responsiveness to bacterial stimulation in asymptomatic patients and patients with bloodstream infection. J Int AIDS Soc 2016; 19: 20759.

18. Syed Ahamed Kabeer B, Sikhamani R, Swaminathan S, Perumal $\mathrm{V}$, Paramasivam P, Raja A. Role of interferon gamma release assay in active TB diagnosis among HIV infected individuals. PLoS One 2009; 4: e5718.

19. Bao L, Li T, Diao N, et al. Fluctuating behavior and influential factors in the performance of the QuantiFERON-TB Gold In-Tube assay in the diagnosis of tuberculosis. PLoS One 2015; 10: e0103763. 
20. Banaei N, Gaur RL, Pai M. Interferon gamma release assays for latent tuberculosis: what are the sources of variability? J Clin Microbiol 2016; $54: 845-50$

21. Herrera V, Yeh E, Murphy K, Parsonnet J, Banaei N. Immediate incubation reduces indeterminate results for QuantiFERON-TB Gold in-tube assay. J Clin Microbiol 2010; 48: 2672-6.

22. Yun JW, Chung HS, Koh WJ, Chung DR, Kim YJ, Kang ES. Significant reduction in rate of indeterminate results of the QuantiFERON-TB Gold In-Tube test by shortening incubation delay. J Clin Microbiol 2014; 52: 90-4.

23. Fabre V, Shoham S, Page KR, Shah M. High proportion of indeterminate QuantiFERON-TB Gold In-Tube results in an inpatient population is related to host factors and preanalytical steps. Open Forum Infect Dis 2014; 1: ofu088.

24. Qiagen. Gnowee - A QuantiFERON reference guide 2018. Available from: http://us-tb.gnowee.net/technical-support [last accessed 22 September 2018].

25. Schablon A, Harling M, Diel R, Ringshausen FC, Torres Costa J, Nienhaus A. Serial testing with an interferon-gamma release assay in German healthcare workers. GMS Krankenhhyg Interdiszip 2010; 5.

26. Tagmouti S, Slater M, Benedetti A, et al. Reproducibility of interferon gamma (IFN-gamma) release assays. A systematic review. Ann Am Thorac Soc 2014; 11: 1267-76.

27. Nemes E, Rozot V, Geldenhuys H, et al. Optimization and interpretation of serial QuantiFERON testing to measure acquisition of Mycobacterium tuberculosis infection. Am J Respir Crit Care Med 2017; 196: 638-48.

28. Rissin DM, Fournier DR, Piech T, et al. Simultaneous detection of single molecules and singulated ensembles of molecules enables immunoassays with broad dynamic range. Anal Chem 2011;83:2279-85.

29. Wilson DH, Rissin DM, Kan CW, et al. The Simoa HD-1 Analyzer: A novel fully automated digital immunoassay analyzer with sin- gle molecule sensitivity and multiplexing. J Lab Autom 2016; 21 : 533-47.

30. O'Connell MA, Belanger BA, Haaland PD. Calibration and assay development using the four-parameter logistic model. Chemometr Intell Lab Syst 1993; 20: 97-114.

31. Qiagen. QuantiFERON ${ }^{\circledR}{ }_{-}$TB Gold Plus $\left(\right.$QFT $^{\circledR}{ }_{-}$Plus $)$package insert 2017. Available from: http://www.quantiferon.com/wp-content/ uploads/2017/10/QFT-Plus-ELISA-IFU-L1095849-R02.pdf [last accessed 22 September].

32. Bilic-Zulle L. Comparison of methods: passing and bablok regression. Biochem Med (Zagreb) 2011;21:49-52.

33. Jung HJ, Kim TJ, Kim HS, et al. Analysis of predictors influencing indeterminate whole-blood interferon-gamma release assay results in patients with rheumatic diseases. Rheumatol Int 2014; 34 : 1711-20.

34. Woo KS, Kim BG, Choi JL, Kim BR, Kim KH. Neutrophilto-lymphocyte ratio Is associated with impaired interferongamma release to phytohemagglutinin. PLoS One 2015; 10: e0125794.

35. Gonzalez-Moreno J, Garcia-Gasalla M, Losada-Lopez I, et al. IGRA testing in patients with immune-mediated inflammatory diseases: which factors influence the results? Rheumatol Int 2018; 38 : 267-73.

36. Person AK, Pettit AC, Sterling TR. Diagnosis and treatment of latent tuberculosis infection: an update. Curr Respir Care Rep 2013; 2: 199207.

37. Komiya K, Ariga H, Nagai H, et al. Impact of peripheral lymphocyte count on the sensitivity of 2 IFN-gamma release assays, QFT-G and ELISPOT, in patients with pulmonary tuberculosis. Intern Med 2010; 49: 1849-55.

38. Lange B, Vavra M, Kern WV, Wagner D. Indeterminate results of a tuberculosis-specific interferon-gamma release assay in immunocompromised patients. Eur Respir J 2010; 35: 1179-82. 